\title{
TRILOGI CELENG DJOKO PEKIK KAJIAN MAKNA MELALUI PENDEKATAN SEMIOTIKA PIERCE
}

\author{
Oleh: Dilla Eka Lusiana \\ Institut Seni Indonesia Yogyakarta
}

\begin{abstract}
ABSTRAK
Lukisan Djoko Pekik yang sering disebut dengan istilah Trilogi celeng tersebut adalah: pertama, Susu Raja Celeng tahun 1996, kedua, Indonesia Berburu Celeng tahun 1998 dan ketiga, Tanpa Bunga dan Telegram Duka tahun 1999. Lukisan Trilogi Celeng merupakan karya yang monumental tidak hanya bagi pelukisnya tetapi kehadirannya pernah tercatat sebagai lukisan termahal pelukisnya. Berkaitan dengan uraian di atas, maka rumusan permasalahan dalam penelitian dapat dijabarkan dalam pertanyaan-pertanyaan sebagai berikut: Mengapa Djoko Pekik membuat tema Trilogi Celeng, Mengapa Djoko Pekik mengangkat Celeng sebagai simbol dalam karya lukisnya dan Bagaimana makna karya Trilogi Celeng ditinjau dari kondisi kontekstual yang melahirkannya. Penelitian difokuskan pada lukisan Trilogi Celeng Djoko Pekik, Penelitian yang akan digunakan jenis deskriptif analitik. "Penelitian deskriptif analitik yaitu suatu cara pemecahan masalah yang diselidiki berdasarkan fakta-fakta yang tampak dengan apa adanya. Dari temuan-temuan didapatkan simpulan tentang aspek-aspek penting yang berkaitan dengan munculnya lukisan-lukisan Trilogi Celeng. Aspek tersebut adalah pengalaman-pengalaman pahit masa lalu yang pernah dialami Djoko Pekik, sedangkan makna Trilogi Celeng merupakan penggambaran fase-fase runtuhnya rezim orde baru.
\end{abstract}

Kata kunci: Djoko Pekik, Trilogi Celeng, Kajian makna

\begin{abstract}
Djoko Pekik's Trilogi Celeng consist of three art works namely: First, the 1996 Susu Raja Celeng, second, the 1998 Indonesia Berburu Celeng and the last one is the 1999 Tanpa Bunga dan Telegram Duka. Trilogi Celeng artwork is Djoko Pekik's most expensive and also monumental masterpiece. Relating to the above description, so I can explained the problem formulation as: Why Djoko Pekik named his masterpiece as Trilogi Celeng?; Why Djoko Pekik use wild boar as the symbol of his masterpiece?; and What is the meaning of Trilogi Celeng reviewed from the contextual condition that delivered by Djoko Pekik? The observation focused on Djoko Pekik's Trilogi Celeng, and I will use descriptive analytic observation. "Descriptive analytic observation is the way to solve problem that explored based on the facts. The conclusion of the important aspects that related with the Trilogi Celeng artwork obtained from the findings. That aspects are the Djoko Pekik's bitter experiences in his past life, while the meaning of Trilogi Celeng is the depiction of the regime Orde Baru collapse phases.
\end{abstract}

Keywords: Djoko Pekik, Trilogi Celeng, Meaning studies

\section{PENDAHULUAN}

\section{A. Latar Belakang}

Karya seni dapat dikatakan sebagai bentuk ungkapan pengalaman serta perasaan dan pikiran seniman. Seni merupakan suatu hasil kreasi yang dipengaruhi oleh faktor internal dan faktor eksternal yang ada pada manusia itu sendiri, seperti pengalaman, pengetahuan, lingkungan (alam, sosial, dan budaya) dan factor 
internal dan eksternal turut mempengaruhi karya seni. Fenomena yang terjadi pada masyarakat sekitar seniman merupakan salah satu bagian yang dapat diangkat sebagai ide atau objek oleh seorang seniman. Realitas yang ada pada masyarakat merupakan salah satu sumber ide yang bisa divisualisasikan ke dalam karya.

Salah satu seniman yang biasa dikatakan peka dengan realitas sosial disekitarnya adalah Djoko Pekik. Cobaan yang dialaminya seperti menjadi tahanan politik mulai 8 November pasca peristiwa G30/S PKI tahun 1965 sebagai dampak dari peran serta aktif Djoko Pekik dalam kegiatan LEKRA membuat ia lebih peka dengan kehidupan disekitarnya.

Sebagai seniman yang dikenal dengan nilai-nilai kerakyatan, maka pada masa Orde lama di Indonesia seolah-olah nama Djoko Pekik melekat pada komunis. Unsur kerakyatan yang diangkat sejalan dengan tujuan berkesenian dari Lembaga Kesenian Rakyat bahwa seni dapat membela rakyat yang sengsara, tertindas, dan menderita. Seiring dengan era globalisasi dan runtuhnya Orde Baru nama Djoko Pekik terangkat melambung tinggi. Ia dikenal dengan seniman lukis yang mengangkat objek-objek celeng (babi) yang dinamakannya dengan Trilogi Celeng.

\section{B. Rumusan Masalah}

1. Mengapa Djoko Pekik membuat tema Trilogi Celeng ?

2. Mengapa Djoko Pekik mengangkat Celeng sebagai simbol dalam karya lukisnya ?

3. Bagaimana makna karya Trilogi Celeng ditinjau dari kondisi kontekstual yang melahirkannya ?

\section{Metode Penelitian}

Penelitian yang akan digunakan jenis deskriptif analitik. "Penelitian deskriptif analitik yaitu suatu cara pemecahan masalah yang diselidiki berdasarkan faktafakta yang tampak dengan apa adanya. Penelitain deskriptif dapat dikatagorikan sebagai suatu penelitian yang menelaah atau menggambarkan tentang suatu objek dan problematika yang umum dan luas, akan tetapi tetap berfokus pada objek penelitian. Penelitian ini dengan demikian mampu mengungkapkan permasalahan dengan berbagai argumentasi yang maksudnya untuk menjelaskan segala aspek 
yang didapatkan untuk dianalisis. Dengan mengerti pentingnya metode deskriptif analitik di dalam penelitian tentang jejak historis karya-karya Djoko Pekik maka dalam penulisan ini digunakan metode tersebut.

Bentuk dan sifat penelitian ini adalah penelitian kualitatif karena dapat diperoleh data-data (transkrip interview, catatan lapangan, fotografi, video rekaman dan dokumen catatan resmi lainnya). Peneliti harus menganalisa, mengolah dan menggali kata-kata dan gambar untuk menguraikan fenomena dalam penelitian. Oleh sebab itu, peneliti harus menggali secara jeli hal-hal yang mempengaruhi pemikiran senimannya seperti biografi kehidupan seniman yang menyangkut lingkungan keluarga, lingkungan masyarakat, lingkungan pergaulan, dan lain-lain.

Trilogi Celeng memiliki dimensi yang lengkap untuk dikaji secara rupa dan historis. Lukisan Trilogi Celeng tidak dapat dilepaskan dari kehidupan senimannya maka diperlukan sebuah pendekatan historik, sedangkan untuk menjawab makna visual dilakukan dengan interpretasi analisis dengan pendekatan semiotika.

\section{PEMBAHASAN}

\section{A. Latar Belakang Kehidupan Djoko Pekik}

Djoko pekik sebagai seorang seniman yang pernah di penjara selama bertahuntahun akibat aktivitasnya dalam organisasi Lekra menjadikan setiap karyanya selalu dipengaruhi oleh tema sosial. Karya-karya seni yang dihasilkan tidak akan lepas dari pengalaman kehidupannya, demikian halnya dengan karya seni lukis yang dikenal dengan Trilogi Celeng merupakan representasi pengalaman batinnya. Dengan kata lain pengalaman hidupnya menjadi wahana kreatif bagi Djoko Pekik dalam berkarya.

Djoko Pekik lahir pada 2 januari 1938 di Desa Karangrejo, Sukosari, Purwodadi, Grobokan. Djoko Pekik lahir dari keluarga petani sederhana dan keluarga yang masih buta huruf karena kondisi ekonomi sehingga tidak memungkinkan untuk sekolah. Ayah Djoko Pekik bernama Karodikromo Gariman sedangkan ibunya bernama Sinem. Dari kedua orangtuanya Djoko Pekik tidak mewarisi bakat kesenian bahkan sejak saat kecil dirinya tidak pernah diharapkan oleh orang tuanya menjadi seorang seniman. 
Upaya Djoko Pekik tidak sia-sia karena terbukti pada 1957 dirinya bisa masuk kejenjang pendidikan lebih tinggi di Akademi Seni Rupa Indonesia (ASRI). Menjelang masuk tahun ketiga masa kuliahnya pihak keluarga sudah tidak sanggup lagi membiayai. Djoko Pekik. Guna memenuhi ambisinya untuk maju dalam pendidikan kedua orang tuanya sampai harus menjual ternak seperti kambing dan sapi. Sejak tahun 1958 -1959 Djoko Pekik bisa membiayai kuliah sendiri dari hasil lukisan yang terjual.

Sistem pendidikan yang diterapkan di ASRI tersebut tentunya berpengaruh terhadap karya seni mahasiswanya. Wajar jika Djoko Pekik kemudian mempunyai gaya sendiri yang citraannya berfokus pada persoalan kehidupan masyarakat di sekitarnya seperti figur-figur kaum buruh atau rakyat jelata. Realitas sosial menjadi tema dalam lukisannya dan tema tersebut tidak berubah sejak di bangku kuliah hingga kini.

Selain menimba ilmu di kampus ASRI, Djoko Pekik sering belajar dan mengadakan diskusi bersama dengan kawan-kawannya seperti Amrus Natalsya, Misbach Tamrin, Isahasanda, Ng.Sembiring. Tema-tema dalam diskusi bukan hanya persoalan seni rupa namun termasuk masalah politik yang pada saat itu situasinya sedang menghangat. cikal bakal berdirinya sanggar Bumi Tarung yang memasang badan sebagai anggota Lembaga seni rupa Lekra dan didirikan pada pertengahan tahun 1961. Keterkaitan sanggar Bumi Tarung dengan Lekra ditegaskan oleh Natalsya sebagai salah satu tokoh penggagas sanggar tersebut bahwa; "kemudian kami membentuk sanggar Bumi Tarung yang anggotanya sekaligus anggota LEKRA”.(Natalsya, 2005: 88)

Peristiwa lubang buaya atau yang dikenal sebagai Gerakan 30 September 65 (G 30 S PKI) berbuntut dibubarkannya LEKRA termasuk di dalamnya sanggar Bumi Tarung. Djoko Pekik dan rekan-rekan sanggar yang tergabung dalam seniman LEKRA ditangkap dan dijebloskan ke dalam penjara tanpa pengadilan yang jelas dan juga untuk batas waktu hukumannya. Sebagai tahanan politik dengan tuduhan terlibat G 30 S PKI situasinya tentu menjadi lain karena aturan yang sangat ketat. Jangankan untuk melukis dengan membawa cat dan kanvas, membawa korek api saja tidak boleh.

Setelah Djoko Pekik dibebaskan dari penjara pada tahun 1972 ternyata situasi tidak memungkinkan untuk bergaul dengan sesama seniman, karena PKI masih dianggap sebagai bahaya laten dan diasingkan oleh masyarakat. Trauma 
masyarakat terhadap peristiwa G 30 S PKI tentunya berbuntut panjang ditambah dengan propaganda rezim orde baru yang menganggap komunis sebagai bahaya laten juga berdampak pada kehidupan Djoko Pekik. Penolakan dan pengucilan terhadap dirinya berlangsung lama bahkan sampai akhir tahun 1990-an seiring dengan meredupnya kekuasaan rezim orde baru yang dipimpin oleh Soeharto.

Sejak tahun 1969 dalam status tahanan luar Djoko Pekik telah menikah. Untuk mencukupi kebutuhan keluarga Djoko Pekik bersedia bekerja apa saja. Selama itu Djoko pekik belum bisa berkarya lagi karena tuntutan hidupnya dan pemenuhan kebutuhan keluarganya. Situasi sulit yang menjadi fokus utamanya adalah bagaimana bisa mempertahankan hidup dirinya dan keluarga. Untuk memenuhi kebutuhan makan Djoko Pekik menjadi seorang penjahit pakaian di Jalan RE. Martadinata Wirobrajan Yogyakarta. Pekerjaan ini digelutinya selama 10 tahun dan selain menjahit pakaian.

\section{B. Realitas Sosial Masyarakat Bawah sebagai Dasar Rangsangan Kreativitas}

Realitas sosial Djoko Pekik merupakan realitas sosial kelas bawah yang menjadi ide kreatif dalam berkarya. Realitas masyarakat yang buruk, keruh dan kumuh bagi Djoko Pekik merupakan realitas Indonesia yang berbeda dengan gambaran realita alam yang indah dan molek. Karya yang dihasilkan merupakan cerminan masyarakat tertindas oleh keadaan atau kondisi pemerintah yang dianggap sebagai pemicu kesusahan pada rakyat. Melihat dari karya-karya yang dihasilkan Djoko Pekik terlihat persamaan dengan Soedjojono dalam menafsir realitas yang direpresentasikan dalam karya.

Apa yang dilakukan Soedjojono dengan cara menggabungkan tradisi melukis realis dengan dua cara sekaligus sama halnya dengan yang dilakukan Djoko Pekik walaupun karakternya berbeda. Cara yang dilakukan Soedjojono adalah realisme dalam maksud keahlian pelukis menggambarkan kenyataan secara benar dan tepat serta realisme dalam maksud yang lebih ideologi” (Siregar, 2004: 15). Dengan penggabungan kedua cara tersebut maka karya-karya Djoko Pekik merupakan ungkapan penderitaan yang dirasakan dari kehidupan orang-orang di lingkungannya. Realitas yang dihadirkan dalam karyanya dapat dianggap kritikan terhadap para penguasa negeri yang menyengsarakan rakyat di tengah-tengah negeri yang subur dan kaya akan sumber alamnya. Lukisan Djoko Pekik merupakan teriakan rakyat yang tertindas. 
Realitas sosial tertindas yang disuguhkan pada karya Djoko Pekik bukanlah bentuk ekspresi semata namun dengan maksud supaya para penguasa memperhatikan masyarakat kecil. Dapat dikatakan bahwa karya lukisannya sebagai alat penyambung lidah antara rakyat kecil dengan penguasa. Kenyataan masyarakat yang ada di sekitarnya dan kondisi rakyat yang semakin susah menjadikan Djoko Pekik tersentuh dan direpresentasikan dalam karyanya. Kehidupan rakyat dalam lukisan bukan hanya sebagai cerminan akan tetapi merupakan cuplikan dari realitas. Karya seni menjadi bagian penting yang dapat membantu agar setiap orang mampu melihat kenyataan bahwa kebenaran mesti diperjuangkan. Meskipun bukan satu hal yang nyata akan tetapi seni bisa dijadikan sumber di dalam pemahaman terhadap eksistensi kemanusiaan yang selalu menjadi bahan diskusi dalam proses memahami kehidupan secara nyata.

Pandangan yang dilontarkan Djoko Pekik tentang lukisannya yang dijadikan sebagai media penyambung lidah rakyat berhubungan dengan peran seni sebagai kritik sosial atau disebut seni untuk masyarakat yang mempunyai fungsi dan manfaat dalam kehidupan. Seni bukan hanya bentuk ekspresi semata, seni untuk seni itu sendiri, atau seni hanya diciptakan untuk keindahan semata seperti halnya pandangan seni untuk seni. Hampir setiap karya seni merupakan ekspresi isi, baik berupa pikiran, perasaan, atau nilai-nilai dalam kehidupan. Seni selalu mempunyai fungsi kenikmatan,tidakhanya keindahan bentuknya, melainkan juga keindahan pada isinya. Dengan kreativitas yang disampaikan melalui isi karya, seni dapat membantu dalam mengekspresikan keberanian seorang seniman dalam melakukan kritik dan dapat mendorong untuk memperbaharui tatanan lama menuju tatanan yang lebih baik. Plato pernah berpendapat bahwa seni yang mengandung hal-hal buruk dan tidak bermoral bagi manusia meskipun indah harus ditolak.

Setiap lukisan yang dibuat Djoko Pekik berdasarkan pada pengetahuan terhadap objek misalnya kehidupan masyarakat kecil merupakan representasi seperti yang pernah ditangkap dengan inderanya kemudian di presentasikan ke dalam bentuk lukisan. Pengetahuan seniman pada setiap objek seperti masyarakat kecil bisa jadi tangkapan indera yang bisa disaksikan setiap hari atau objeknya dapat ditemui dalam keseharian disekitar tempat tinggalnya. Djoko Pekik menangkap objek dari kehidupan sehari-hari tetapi dari sana terbersit isyarat tentang sesuatu yang penuh lambang dengan guratan gairah dan emosi yang 
terkadang sayu, terkadang lucu, dan terkadang marah. Karakteristik pelukisan yang begitu kuat dan mengesankan dapat dilihat salah satunya dalam lukisan yang berjudul Keretaku Tak Berhenti Lama.

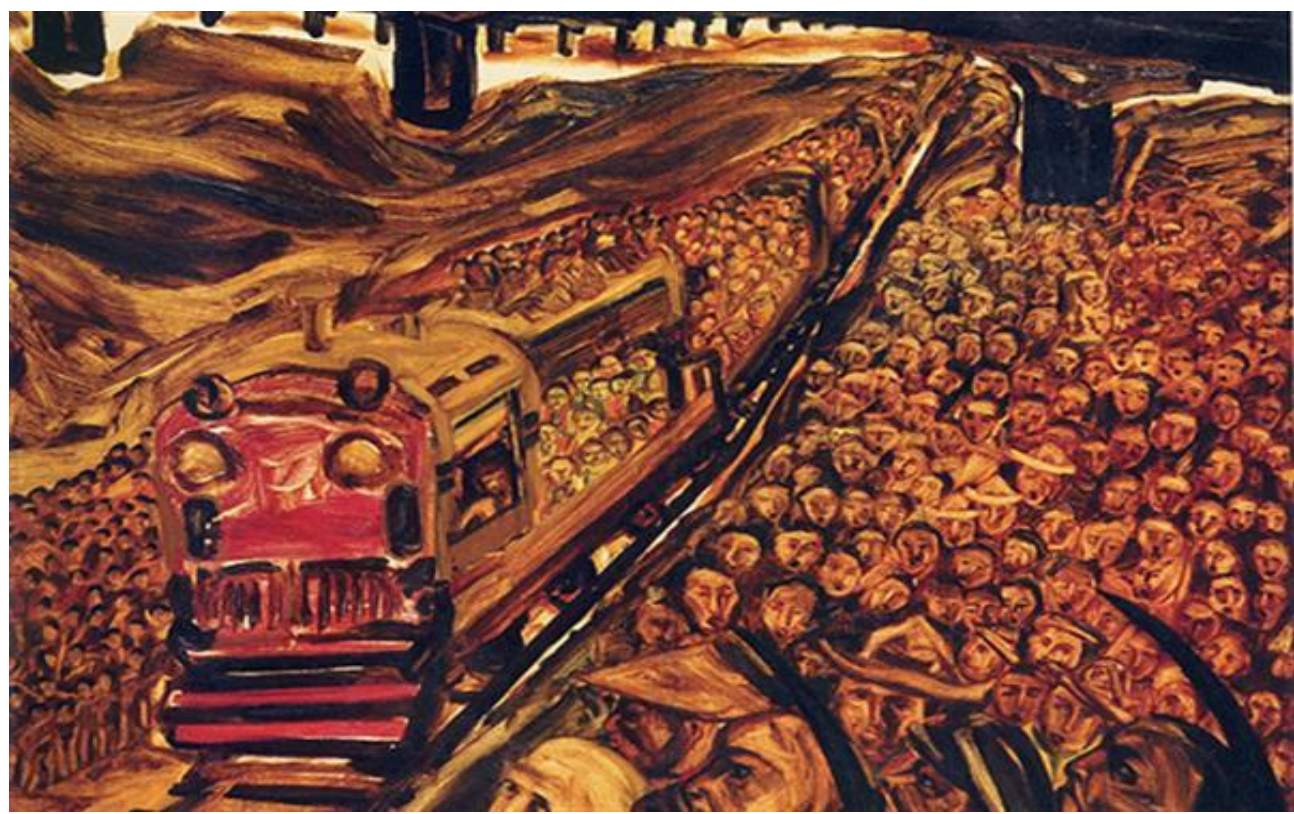

Gambar 1.

Djoko Pekik, KeretakuTakBerhenti Lama, 1989, Oil on canvas (Foto: Dilla Eka Lusiana, 2013)

Kedekatan Djoko Pekik dengan objek berpengaruh pada setiap karya lukisnya. Apa yang diketahuinya tentang kehidupan masyarakat bawah digambarkan secara utuh sehingga karyanya dapat menyentuh perasaan bagi yang melihat. Djoko Pekik memang dekat dengan objek yang berada di lingkungannya, namun kedekatan tersebut bukan pada bentuk-bentuk lainnya, melainkan pada hakikat yang ada di dalamnya. Dalam hal ini tentunya menarik untuk disimak tentang pandangan Veron dalam hubungannya dengan lukisan dalam suatu karya yang mengatakan bahwa "kehebatan suatu karya seni bukanlah dilihat dari apakah karya itu menyenangkan atau tidak melainkan dari seberapa dalamkah gerangan kehidupan jiwa yang diekspresikan itu berasal',

Djoko Pekik dan para seniman lainnya yang aktif di sanggar Bumi Tarung melakukan propaganda dan menjalin hubungan antara seniman dengan rakyatnya. Dalam konteks karya semua lukisan Djoko Pekik pada era enampuluhan selalu berisikan tentang kehidupan atau realitas sosial pada saat itu. Empati yang terbangun dalam karyanya bukan hanya sekedar mengamati kehidupan rakyat namun integrasi dirinya dengan rakyat sebagai objek lukisannya. Empati yang tumbuh banyak ditemukan Djoko Pekik manakala bersama dengan LEKRA 
menjalankan metode berkreasi dari teori 'satu lima satu'(1-5-1) dan melakukan aksi turun ke bawah (turban).

Lukisan berjudul Tuan Tanah Kawin Muda merupakan contoh karya yang dibuat hasil dari pengalaman dari turun ke bawah. Lukisan merupakan gambaran keberpihakan Djoko Pekik pada wong cilik yang pada saat itu tanahnya dirampas dan membantu masyarakat tertindas untuk mendapatkan tanah-tanah yang dirampas. Peristiwa tersebut di tuturkan Djoko Pekik yang mengungkapkan bahwa 'itulah yang kemudian saya gambar tuan tanah Haji Dawan Roji, karya tersebut merupakan hasil pengamatannya dengan cara turun ke bawah (turba)'” .

Karya tersebut membuktikan kecerdasan pikiran dan kepekaan Djoko Pekik terhadap kehidupan sosial masyarakat. Pengalaman hidup keluarganya yang miskin menjadikan Djoko Pekik selalu peduli terhadap kehidupan dan nasib orang lain atau masyarakat tertindas yang hak tanahnya dirampas. Barangkali memang begitulah kecenderungan seni rupa ketika dirinya menjadi bagian dari program resmi. Di tahun 1962 di masa revolusi terpimpin Menteri Pendidikan dan Kebudayaan menekankan agar Kesenian modern kita harus bergaya realism artinya supaya rakyat mengerti apa yang disajikan dan kesenian itu juga harus bernafaskan sosialisme',.

Realitas yang dipilih Djoko Pekik adalah realitas masyarakat kelas bawah. Penggambaran kesenjangan itu dapat dilihat misalnya pada karya berjudul Pengamen yang mencitrakan seorang pengamen tradisional khas jawa sedang duduk dengan pintu dan gembok yang kokoh menjadi latar di belakang berpadu dengan jembatan layang, gedung-gedung bertingkat dengan objek utama lukisan, perempuan dengan membawa aneka jajanan di kepalanya. Lukisan dengan mengambil tema yang diangkat dari realitas sosial atau kehidupan sehari-hari dapat dilihat juga pada karya berjudul 'Berstagen Merah', Realitas sosial semacam itulah yang menjadi pilihannya dan banyak di sajikan dalam lukisannya. 


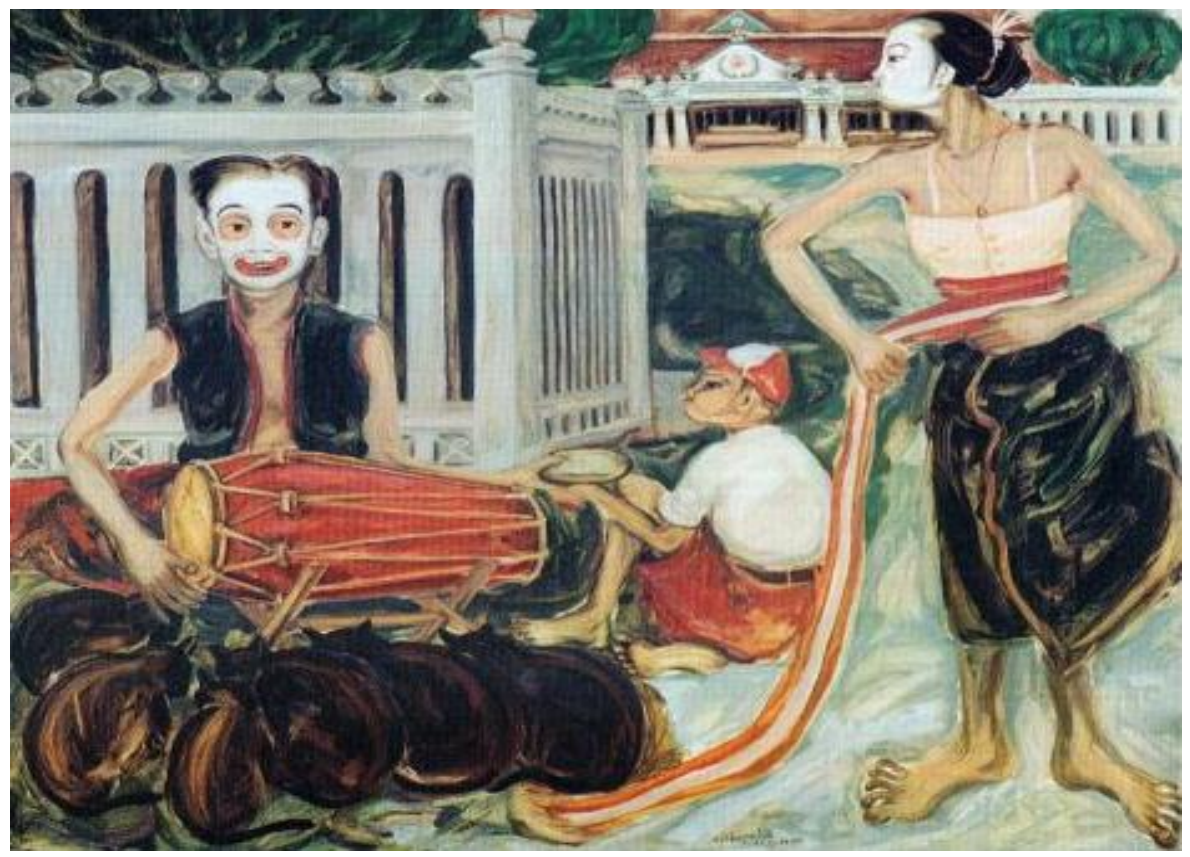

Gambar 2.

"'Berstagen Merah Bangun Kota', 1990, 175x150cm (Reproduksi dari Katalog pameran tunggal Lukisan Djoko Pekik)

Konsep yang dibangun oleh Djoko Pekik dilakukan berdasarkan keinginan menjadi bagian dari fenomena yang divisualisasikannya, walaupun saat ini Djoko Pekik tidak lagi menjadi seorang yang mengalami penderitaan secara langsung. Penderitaan yang dirasakannya merupakan bentuk empati yang didapat pada saat melihat kehidupan masyarakat bawah atau banyak ditemukan manakala dirinya jalan-jalan kesuatu tempat. Kedekatan rasa antara Djoko Pekik dengan kaum lemah merupakan sikap empati terutama pada penderitaan mereka. Rasa empati terhadap realitas sosial bukan hanya persoalan rasa simpati namun menyatu dengan pengalaman hidupnya.

Citraan dalam ukisan Djoko Pekik seolah menyerukan agar penderitaan rakyat diperhatikan karena rakyat tarus menerus didera penderitaan dalam hidupnya akibat dari kesalahan sistem. Di mata Djoko Pekik masyarakat dengan segala penderitaanya dianggap manusia-manusia yang pasrah dan tidak berdaya untuk menyuarakan hati nurani. Olahan citraan dalam karya menjadi mediator dan Djoko Pekik berusaha menembus batas-batas untuk memberi daya pada masyarakat dengan maksud mengusik perasaan masyarakat kelas atas.

Empati yang muncul dalam dirinya merupakan hakekat kehidupan orang kecil dan ini diperkuat dari hasil tangkapan semua indera mengalami dan merasakan. Intergrasi keduanya menjadikan citraan yang sangat kuat dan 
mengungkapkan realitas hidup. Dapat dikatakan karya lukisnya merupakan curahan pengalaman-pengalamannya misalnya kedekatan dirinya dengan para penari ledek dalam acara tayuban yang digambarkan dalam karya di bawah ini :

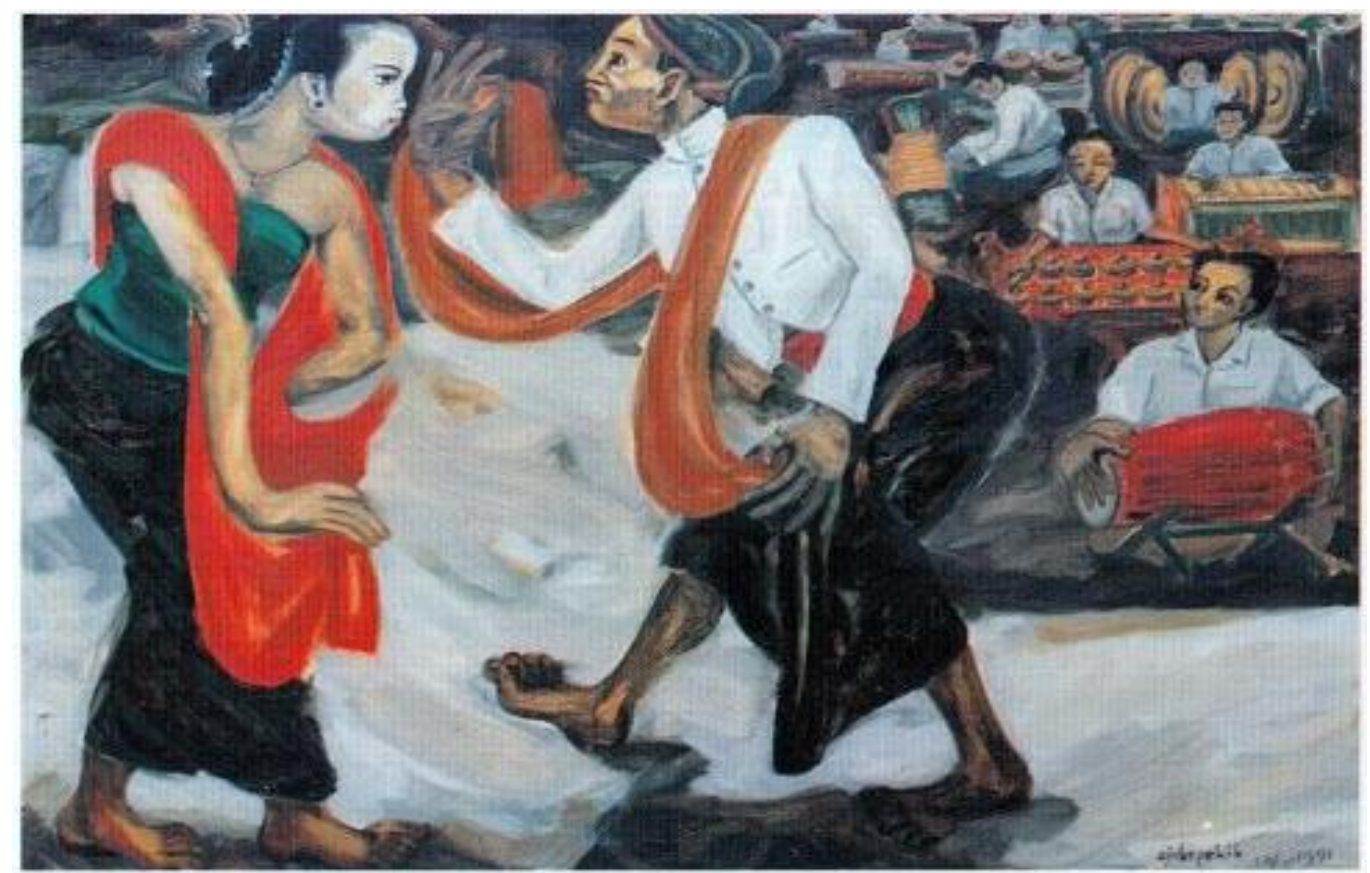

Gambar 3.

"Tayuban", 1991, 140x100cm.

(Reproduksi dari katalog pameran tunggal Lukisan Djoko Pekik).

Setiap orang yang melihat karya-karya Djoko Pekik mempunyai interpretasi sendiri tentang tema yang dihadirkan. Hampir semua lukisan Djoko Pekik bercerita tentang kehidupan rakyat jelata. Tema yang ditampilkan Djoko Pekik merupakan tema sosial atau tema tentang kehidupan masyarakat kelas bawah dengan segala ekspresinya. Ekspresi-ekspresi yang dihasilkan Djoko Pekik dalam karya-karyanya dibalut dan disampaikan dengan bahasa dirinya sendiri. Djoko Pekik kadang memakai bahasa lugas tetapi sering juga memakai idiomidiom yang ada misalnya dalam masyarakat pedesaan.

Idiom yang ada pada masyarakat sekitar termasuk pada lukisan yang mencuatkan dirinya yaitu Trilogi Celeng. Munculnya tiga buah lukisan Djoko Pekik yang menampilkan objek atau fokus utama berupa citra celeng tentu memiliki alasan dan latar belakang tersendiri. Tiga lukisan tersebut yaitu Susu Raja Celeng, Indonesia 1998 Berburu Celeng, dan Tanpa Bunga Dan Telegram Duka. 


\section{Celeng sebagai Media Ekspresi}

Celeng merupakan ungkapan kekesalan Djoko Pekik yang keluar dari mulut ketika melampiaskan kemarahannya pada Soeharto sebagai penguasa rezim orde baru saat dalam penjara. Djoko Pekik mempunyai keinginan untuk mengekspresikan pengalaman yang dirasakan dan dialaminya sehingga memunculkan keinginan untuk menggambarkan orang yang telah menghancurkan kehidupannya. Soeharto dianggap sebagai orang yang telah membuatnya menderita, orang yang memerintah secara otoriter, seorang yang kejam, penguasa yang berbuat seenaknya sendiri, dan penguasa yang tak pernah merasa kenyang akan kekuasaan dan harta. Hal-hal tersebut sering memunculkan kekesalannya dengan wujud umpatan asu, bajingan, dan celeng. Umpatan-umpatan tersebut terungkap pada saat menceritakan kembali pengalaman pahitnya semasa dipenjara.

Gambaran pengalaman pahit yang dialami Djoko Pekik. Penjeblosan dirinya ke penjara akibat dari peristiwa yang terjadi pada 1965 yang dikenal dengan peristiwa G 30 S PKI. Penderitaan panjang yang dialaminya sebagai tahanan merupakan pukulan yang luar biasa. Sebagai seorang tahanan dirinya tidak bisa berbuat banyak hanya umpatan yang selalu berkecamuk dalam hatinya. Pikirannya kalut luar biasa yang memunculkan pertanyaan kenapa diperlakukan seperti itu pada hal dirinya tidak melakukan tindakan apapun. Dapat di bayangkan betapa sedih dan hancur hati Djoko Pekik ketika dirinya harus dipenjara. Djoko Pekik harus menghapus semua mimpidan cita-citanya yang telah dirintis begitu lama. Dirinya harus memendam dalam-dalam segala keinginan-keinginannya. Keseharian hidupnya di dalam sel tahanan merupakan hari-hari penuh perjuangan yang dirasakan begitu panjang. Peristiwa yang dialaminya dengan hidup di dalam rumah tahanan selama tujuh tahun meninggalkan bekas yang teramat dalam dan sulit untuk dilupakan.

Pikiran, hati perasaannya terus berontak terhadap kenyataan-kenyataan yang dialami dan seolah menjadi tumbal yang dikorbankan rezim orde baru. Dalam kesendirian dirinya sering merenungkan atau mengenang kembali peristiwa-peristiwa yang dialami. Pikiran tersebut selalu muncul di tengah-tengah penderitaanya dalam kurun waktu antara 1965 sampai 1972. Perenungan tersebut menumbuhkan keinginan untuk mengadakan perlawanan terhadap rezim penguasa orde baru. Di tengah-tengah penderitaan yang dialami dirinya masih menganggap 
sebagai orang yang beruntung karena ditakdirkan masih hidup walaupun dengan kondisi sangat menggenaskan. Banyak rekan-rekan yang mengalami hal serupa atau satu tahanan meninggal dunia karena tidak tahan dengan segala kondisi di sana(Djoko Pekik: 2013).

Perenungan Djoko Pekik memang terasa panjang dan pisuhan-pisuhan pun terasa keras. Sesekali pikiran kreatifnya menyeimbangkan kesadarannya untuk bertahan hidup. Kesadaran untuk mengekspresikan isi hati ke dalam bentuk karya terasa jelas. Celeng adalah hal yang dapat mewakili perasaan hati dan pikirannya. Celeng dapat mengakomodasikan ide karena celeng menurut dirinya adalah simbol angkara murka. Dengan kata lain celeng dalam lukisan bukanlah sekedar gambar binatang tetapi merupakan simbol keserakahan, ketamakan, dan kesombongan. Keangkaramurkaan dalam benak Djoko Pekik dapatlah dimaknai sebagai hidup serakah, nggugu karepe dhewe, mau menang sendiri atau sering disebut otoriter. Celeng menurut Djoko Pekik mempunyai makna lain cocok dengan sifat-sifat pada orang yang membuat dirinya menderita.

Kehidupan celeng sebenarnya banyak dilingkupi dengan hal-hal yang negatif. Manusia memandang bahwa sifat celeng selalu merusak dan rakus. Celeng sering masuk di area pertanian berakibat rusaknya tanaman para petani sehingga sering disebut sebagai musuh petani. Sifat lain yang dipahami oleh pelukis adalah bahwa binatang celeng sepertinya tidak mengenal kata kenyang. Pada masyarakat Jawa celeng selalu dihubungkan dengan mitos yang berkembang dengan adanya celeng jadi-jadian yang disebut babi ngepet. Orang bisa menjadi babi ngepet jika seseorang telah mengatakan diri bersekutu dengan setan hanya untuk mengejar kekayaan semata.

Berdasarkan pandangan terhadap celeng maka dapat ditarik pada suatu kesimpulan bahwa celeng yang dikenal di masyarakat Jawa baik celeng asli, celeng cerita, ataupun mitos yang berkembang merupakan hal yang memiliki tabiat negatif. Celeng dapat memakan apa saja seperti: ketela, jagung, atau padi dan setelah kebutuhannya terpenuhi atau perutnya kenyang tidak langsung pergi namun akan membawa makanan yang didapatnya ke rumah untuk dijadikan makanannya sendiri dan keluarganya. Hal tersebut hampir sama dengan celeng jadi-jadian yang dapat menyedot uang orang lain habis-habisan untuk memperkaya dirinya. 
Celeng jadi-jadian atau bisa disebut babi ngepet biasanya suka mendatangi kediaman orang yang usai menyenggarakan hajatan karena rumah tersebut dianggap menyimpan harta karun berupa uang atau barang hasil dari sumbangan para undangan. Harta karun yang tersimpan dengan mudah disikat habis oleh babi ngepet tanpa diketahui pemiliknya yang terlelap tidur. Bagi masyarakat yang wilayahnya sering kehilangan maka orang di punya hajatan biasanya akan menutup got atau lubang saluran air dengan kotoran. Kedua tempat tersebut diyakini sebagai tempat babi ngepet menunggu dan menyedot semua uang dan jika saluran itu tertutup maka akan sulit bagi babi ngepet melakukan aksinya. Kelakuan babi ngepet inilah yang dijadikan idiom dalam lukisan Djoko Pekik artinya pemilihan celeng sebagai tema merupakan kesamaan sifat antara babi dengan manusia. Idiom celeng yang digunakan Djoko Pekik dalam karyanya.

Pengungkapan ide tantang celeng tersebut baru terealisasi pada 1996, menurut Djoko Pekik latar belakang kemunculannya sudah ada sejak tahun 1965. Hal tersebut tentunya memunculkan pertanyaan baru mengapa pengekspresian atau perwujudan celeng baru terealisasi pada tahun 1996. Djoko Pekik mengungkapkan tentang kemunculan celeng yang membutuhkan waktu begitu panjang mulai awal latar belakang tahun 1965 sampai 1996 dikatakan dengan berbagai argumen, bahwa yang harus dilakukannya adalah sluman slumun slamet yang artinya dirinya mencari keselamatan dalam hidup. Bagi rakyat Indonesia tentunya dapat merasakan kekuatan orde baru begitu besar dan luar biasa karena dirinya masih mempunyai keinginan untuk hidup maka sistem yang dianutnya adalah sluman slumun slamet.

Sistem yang digunakan justru menampakan kehati-hatian di tengah kondisi sosial politik pada masa kekuasaan orde baru. Djoko Pekik banyak melihat persoalan ketimpangan dan tercerabutnya hak yang dirasakannya sendiri dan dialami oleh para aktivis atau seniman lain. Sebut saja Rendra yang pernah disidang akibat dari kritikan yang tajam pada penguasa negeri lewat puisipuisinya. Puisi yang ditulis Rendra mengakibatkan terjadinya pencekalan dan pelarangan membacanya atau pementasan teater selama puluhan tahun. Hal lebih parah dan tragis dialami Widji Tukul yang tiba-tiba hilang entah ke mana kemudian dianggap mati dan tentunya hal serupa banyak dialami oleh para aktivis lainnya. Rentetan peristiwa hilangnya atau kematian para aktivis dan seniman ditambah dengan pengalaman dirinya yang pernah dijebloskan ke penjara 
menjadikan sikap kehati-hatian dalam membuat karya apalagi untuk kepentingan pameran yang akan dilihat banyak orang. Lukisan bertemakan celeng baru dikeluarkan dan dipamerkan dalam rangka ulang tahun sewindu berkuasanya Sultan Hamengku Buwono (Djoko Pekik: 2013).

Pernyataan Djoko Pekik di atas merupakan penjelasan tentang mengapa lukisan tersebut baru muncul dikarenakan kekuasa dari penguasa begitu luar biasa sehingga Djoko Pekik memilih untuk mencari aman karena keberadaannya sebagai status bekas tahanan politik terus mendapat sorotan. Pantauan dari penguasa dan aparat keamanan terhadap segala aktifitasnya sangat dirasakan sehingga memaksa Djoko Pekik untuk berpikir bagaimana cara memvisualisasikan gagasan serta perenungannya terhadap situasi dan peristiwa yang dialaminya. Kehati-hatian berimplikasi pada kejelian dalam memilih dan menggunakan simbol sehingga akan memunculkan tafsir lain dari para apresiatornya. Djoko Pekik mengekspresikan isi hatinya tentang kehidupan dan peristiwa yang pernah dialaminya yang secara khusus berhubungan dengan Soeharto divisualisasikan ke dalam karya lukisnya berjudul Trilogi Celeng.

\section{Latar Belakang Lukisan Trilogi Celeng}

Trilogi adalah istilah yang diberikan oleh Djoko Pekik pada karya lukisnya yang berjumlah tiga buah karya lukis yang mengpresentasikan objek utamanya celeng. Trilogi sendiri yang artinya tiga satuan yang saling berhubungan dan mengembangkan satu tema atau tiga hal yang saling bertaut dan saling bergantung, jadi Trilogi Celeng merupakan citraan berupa rangkaian peristiwa yang merepresentasikan celeng sebagai objek utama. Lukisan Djoko Pekik yang kerap disebut dengan istilah Trilogi Celeng tersebut diataranya adalah: pertama, Susu Raja Celeng 1996, lukisan kedua Indonesia Berburu Celeng 1998, dan yang ketiga yaitu Tanpa Bunga dan Telegram Duka 1999.

\section{a. Latar Belakang Lukisan Trilogi Celeng I (Susu Raja Celeng)} Tiga karya yang sering disebut Trilogi Celeng Djoko Pekik ini, lebih menyuguhkan simbol atau perlambangan. Celeng di situ bukan celeng sebenarnya tetapi simbol yang menggambarkan keangkaramurkaan dan kerakusan. Ketiga lukisan tentang celeng ini memiliki keterkaitan dengan yang lainnya berdasarkan pada judul-judulnya yakni: Susu 
Raja Celeng 1996, Indonesia 1998 Berburu Celeng, dan Tanpa Bunga dan Telegram Duka Cita 2000. Ketiga lukisan merupakan tahap-tahap runtuhnya rezim orde baru atau rezim Soeharto.

Tahap awal celeng dalam karya lukisan bertajuk Susu Raja Celeng dibuat pada tahun 1996 dan ukuran 180x150 cm. Lukian tersebut lahir bersamaan dengan peristiwa Gelar Budaya Rakyat memperingati sewindu naik tahta Sri Sultan Hamengku Buwono X. Sebelum acara tersebut dilaksanakan Sri Sulatan Hamengku Buwono $\mathrm{X}$ mengundang para seniman dan menantang kreativitas mereka untuk menyuguhkan isi karya sebenarnya dan berbicara apa adanya tanpa tendeng aling-aling. Seniman diberikan kebebasan untuk mengungkap fenomena atau kritik tanpa harus ragu dan Sri Sultan Hamengku Buwono $\mathrm{X}$ akan bertanggung jawab atas semuanya. Djoko Pekik berkeinginan melukis sesuatu yang keras bermuara pada gagasan tentang raja atau pemimpin yang ideal.

Ketajaman Djoko Pekik sebagai seorang perupa dalam mengungkap realitas atau fenomena sehingga citraan yang dibuat dapat menyuguhkan bentuk dari sudut pandang yang berbeda. Kanvasnya adalah rekaman penderitaan rakyat dan sapuan warnawarna terlihat sederhana tanpa banyak campuran. Dalam menggambarkan seorang raja tentunya sangat paradoks dari idealnya seorang raja walaupun merindukan seorang pemimpin yang benarbenar berpihak kepada rakyat. Djoko Pekik melukis tentang raja yang buruk, pemimpin yang menindas rakyat, dan memperkaya diri sendiri dengan segala cara. Suatu watak yang mendekati sifat celeng atau babi hutan dan tentunya raja ideal bukanlah seperti citraan berupa raja celeng.

Lukisan Trilogi Celeng pertama Susu Raja Celeng, ini digambarkan sosok celeng yang tumbuh dengan enam susunya terlihat besar-besar dengan latar belakang ribuan orang yang memandang dan tak berani mendekat. Celeng menjadi metafora yang berhubungan dengan pengaruh kekuasaan yang masih bertahan atau sosok penguasa yang dibencinya. 


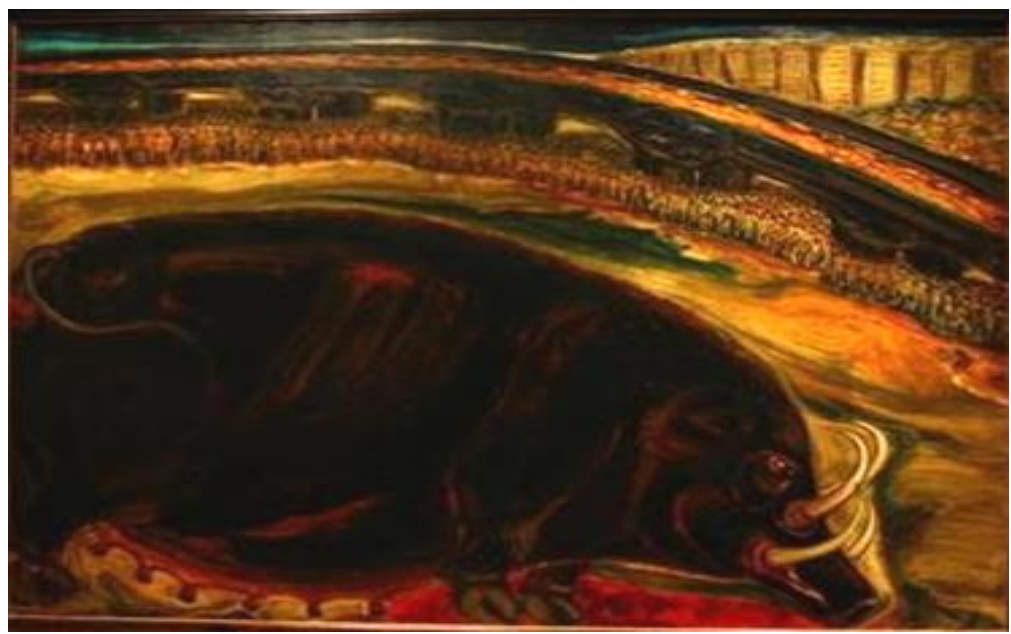

Gambar 4.

"Susu Raja Celeng", 1996, oil on canvas.

(Foto: Dila Eka Lusiana)

Sifat mementingkan diri sendiri itu dapat dilihat dalam penguasaan susu celeng yang ditonjolkan sebagai bentuk kekuasaannya yang disiapkan untuk kelangsungan hidup dirinya sendiri dan anak-anaknya. Dengan kata lain kekuasaan yang diembannya hanyalah untuk kepentingan sendiri dan keturunannya. Lukisan bertajuk Susu Raja Celeng merupakan sarana pengungkap unek-unek yang selama ini disimpan dan dipendam lama. Dengan kata lain Susu Raja Celeng merupakan representasi pengungkapan ide, gagasan, unek-unek, dan umpatan tentang celeng terhadap penguasa rezim orde baru.

Djoko Pekik tampaknya cenderung menggambarkan apa yang sifatnya umum, mempunyai kecenderungan mengungkapkan gagasan tentang golongan, dan tidak tertarik membuat potret tentang individu atau kasus individual. "Djoko Pekik memakai simbol dalam citraannya berupa kasus individual untuk menarik ke dalam gagasangagasan yang umum. Hal-hal di atas dapat dilihat dalam serpihan catatan Yuliman tentang karya seni lukis Djoko Pekik yang menyatakan kecenderungan simbolisasi dan simbolisme di dalam yang individual, konkret, dan khusus cenderung melihat gagasan yang abstrak atau sifatnya umum”. Yuliman memberi keterangan berupa kesimpulan-kesimpulan kecil tentang seni lukis Djoko Pekik ini dengan mencontohkan beberapa karya lukisnya sebagai acuan pada 
karya: Kerbau Tua (Mesin Tua, 1979), Stasion KA Ngabean (Bekas Stasion KA, 1988), Sampah Terompet Terserak di Jalan (sampah terompet di pagi Tahun Baru, 1989)(Yuliman, 1976: 25).

Melihat karya-karyanya bisa jadi ada dua cerita yang secara bersama-sama dapat ditangkap dalam sebuah lukisan karya Djoko Pekik, yaitu tema dari realitas. Pemaknaan dapat ditelusuri melalui objek-objek yang ada pada lukisan tersebut dan tema dibalik visual yang sering disebut bahasa simbolik yang ada di balik objek visual. "Djoko Pekik sering mengkaburkan sebuah gagasan dengan menyandingkan dua objek ke dalam sebuah lukisan. Seperti diungkapkan Yuliman, bahwa: pikiran Djoko Pekik yang melihat gagasan di dalam objek konkret ketika melihat beberapa karya tertentu, ironi yang terselubung dalam kerancuan(ambiguitas)"(Ibid, 1976: 25).

Seniman memang membebaskan setiap orang dalam menginterpretasikan setiap karya lukisannya. Begitu juga dengan lukisan-lukisan yang sering disebut Trilogi Celeng, apresiator dibiarkan untuk mengamati dan dibebaskan dalam menafsirkan. Celeng dalam Susu Raja Celeng dapat diartikan sebagai simbolik penguasa, pemimpin yang mempunyai sifat seperti binatang celeng, rakus, maunya sendiri, jalannya kaku, dan seterusnya. "Djoko Pekik memperlihatkan kepiawaiannya ketika bercerita tentang celeng senyatanya manakala suatu sistem memberlakukan peraturan ketat atau sensor terhadap karya-karya yang berbau kritik. Penggunaan simbol celeng menjadikan Djoko Pekik aman, karena dirinya bisa berkilah bahwa hanya melukis tentang celeng. Citraannya hanyalah celeng gemuk yang memiliki enam susu sedang mengamuk disebuah kota. Hal tersebut terungkap manakala setiap orang menanyakan pada dirinya siapakah celeng itu?. Pasti akan dijawab tergantung interpretasimu, kalau pikiranmu rusuh celeng itu bisa jadi orang yang acap kamu hujat selama ini, bagi saya, celeng ya celeng wong saya hanya menggambar celeng"(Djoko Pekik: 2013).

Visualisasi seekor celeng dalam pengungkapan ekspresi gagasannya tidak lepas dari pengaruh zaman atau orde yang turut 
membentuk seniman dalam mengungkapkan idenya melalui simbolsimbol tertentu dengan harapan selamat atau sering dikatakan Djoko Pekik "sluman slumum slamet". Hal tersebut dapat diartikan sebagai buah pikiran, ide, atau gagasan tersampaikan tetapi dapat lolos sensor dari penguasa. Kehadiran sebuah karya seni didorong oleh banyak keinginan atau motivasi. Hal-hal yang melatarbelakangi lukisan Djoko Pekik dapat dirangkum dalam beberapa hal antara lain:

- Dorongan situasai di mana pada masa tersebut Djoko Pekik merasa penguasa yang dimaksud semakin menjadi kuat sehingga digambarkan dengan Susu Raja Celeng yang masih kokoh berkuasa.

- $\quad$ Kondisi negeri yang mendambakan sosok penguasa yang dapat mengayomi rakyat dan tidak mementingkan diri sendiri.

- Pelepasan emosi yang terpendam sejak lama akibat perlakuan penguasa orde baru sehingga dirinya harus menanggung penderitaan yang panjang terutama ketika berada di penjara. Celeng merupakan representasi kebencian terhadap sosok penguasa orde baru (Soeharto) yang diambil dari salah satu umpatan ketika di dalam penjara yaitu asu, bajingan, atau celeng.

\section{b. Latar Belakang Lukisan Trilogi Celeng II (Indonesia 1998 Berburu Celeng)}

Peristiwa pada 1998 merupakan tonggak sejarah bagi bangsa Indonesia. Fenomena tersebut menjadi sejarah besar bagi Negara ini yang ditandai dengan lengsernya Soeharto dari jabatan kepresidenan setelah menjabat selama 32 tahun. Berhentinya Soeharto disambut gembira oleh segenap rakyat di seluruh pelosok negeri ini, walaupun pada saat yang sama masih menyisakan duka karena nyawa manusia melayang dalam kerusuhan Mei. Gegap gempita rakyat dalam menyambut kemenangan tergulingnya pemerintah rezim orde baru direpresentasikan oleh Djoko Pekik dalam karyanya yang bertajuk Berburu Celeng.

Citraannya merupakan dokumentasi peristiwa walaupun tidak naturalis seperti halnya lukisan Raden Saleh. Citraan tersebut tentunya 
memunculkan banyak tafsir dari para pengamat seni. Sebagian pengamat seni menilai bahwa realisme pada lukisan tersebut merupakan suatu lukisan yang mudah secara teknis, dimengerti rakyat, dan secara idiologis mengabdi rakyat. Setidaknya konsepsi dalam karyanya berdasarkan pada pengalaman-pengalaman ketika berhubungan dan melihat kesenian tradisonal. Walaupun lukisan tersebut dianggap mudah secara teknis namun suguhan karyanya justru semakin meneguhkan komitmennya sebagai pelukis yang tidak mengesampingkan begitu saja lingkungannya.

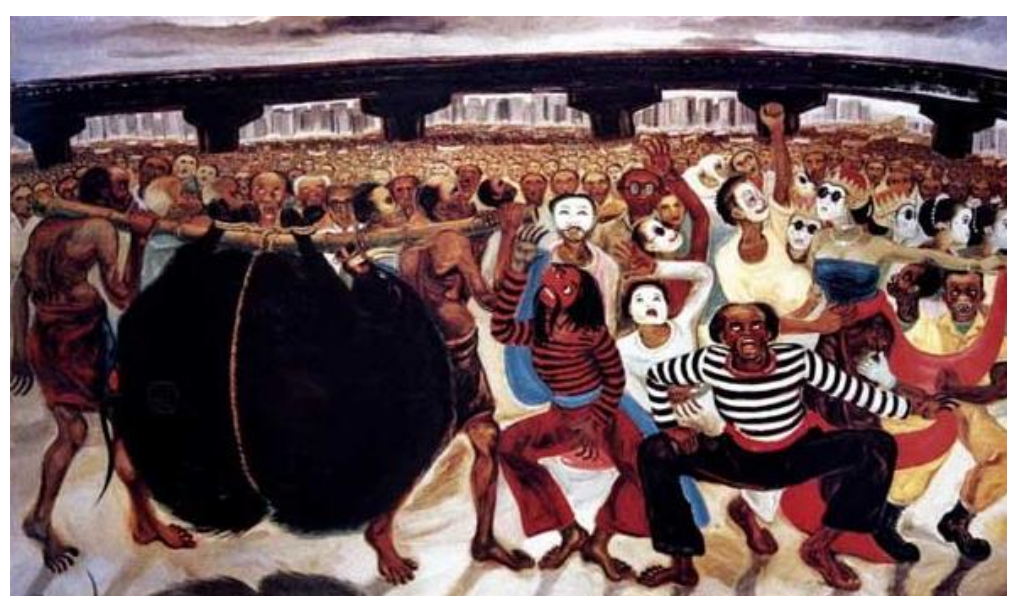

Gambar 5.

"Indonesia 1998 Berburu Celeng" (Foto: Dilla Eka Lusiana, 2013)

Situasi dan kondisi yang berkembang di tanah air, menjadi salah satu ide dasar yang melatar belakangi munculnya lukisan Trilogi Celeng Djoko Pekik ini. Peristiwa lengsernya Presiden Soeharto dari tahta kepresidenan menjadi hal yang menarik untuk diangkat menjadi sebuah lukisan. Lukisan yang berkesinambungan sering disebut Trilogi Celeng ini yaitu Indonesia 1998 Berburu Celeng, adalah rentetan kedua setelah lukisan bertajuk Susu Raja Celeng. Pada lukisan pertama Susu Raja Celeng digambarkan bahwa celeng ini sampai tahun 1996 masih berkuasa penuh atas wilayah kekuasaannya dan mempunyai kekuatan yang besar, tatapi pada 1998 ini celeng digambarkan dalam kondisi tidak berkutik.

Lukisan Djoko Pekik Indonesia 1998 Berburu Celeng ini saat diamati, membawa pelihatannya kesebuah kota entah 
berantah.Citraannya memperlihatkan jembatan layang dan gedung raksasanya yang membentuk perspektif seakan berada pada sebuah kota modern di Indonesia. Gedung-gedung dalam perspektif itu seakan menjadi benteng atau background yang memagari kota. Sulit rasanya benteng-benteng kuat dan megah itu ditembus oleh apapun, apalagi oleh kekuatan manusia yang lemah. "Tetapi siapakah yang dapat menghalangi kekuatan rakyat? Lihatlah di Yogya, pada 20 Mei 1998 lalu, beribu-ribu rakyat mengalir bagai banyu gumrojog"(Djoko Pekik: 2013).

Benteng kota yang megah itu akhirnya jebol, dan rakyat terus mengalir bagaikan banyu gumrojog (air membajir). Mereka membanjiri kota dan dari kejauhan yang nampak hanyalah lautan kepala-kepala manusia. Ditengah-tengah lautan massa nampak figurfigur manusia yang mengangkat spanduk-spanduk sepertisedang demonstrasi. Spanduk-spanduk itu berada dalam perspektif yang sangat jauh, hingga tidak mungkin terbaca tulisannya. Mungkin spanduk itu bertulisan demokrasi, reformasi, atau bisa juga turunkan harga dan lain-lain. Citraan tumpah ruahnya rakyat memenuhi kota layaknya air bah menjadi latar belakang. Rakyat yang tumpah bagaikan air bah itu bukan sedang melakukan demonstrasi namun sedang berburu celeng.

Cerita utama dalam lukisan tersebut adalah seekor celeng yang tertangkap. Hal tersebut bisa terungkap dengan jelas di mana celeng sebagai objek utama digambarkan dengan menggunakan aksen warna hitam yang ditempatkan di belahan kiri. Kesan tersebut sangatlah kuat ditambah dengan penggambaran bentuk tubuhnya yang besar gemuk, dan bulat dalam kondisi terikat dan ditandu dua figur manusia kerempeng kurus kering. Taringnya indah dan perkasa sebagai perwujudan sebagai martabatnya namun betapapun besar dan perkasanya celeng itu tampak tak berkutik.

Fenomena tahun pada 1998 ditandai dengan adanya peristiwaperistiwa demonstrasi besar-besaran hampir di seluruh kota-kota besar di Negeri yang carut marut ini. Kondisi tersebut menjadi ide utama atau hal yang melatar belakangi lukisan Indonesia 1998 Berburu 
Celeng. Kondisi celeng yang tidak berkutik oleh para pemburu celeng yang tidak lain adalah masyarakat Indonesia di tahun 1998 tersebut digambarkan dengan jelas oleh pelukis bahwa citraannya merupakan representasi kondisi ketika celeng yang ditakuti betul-betul tidak bekutik lagi.

Peristiwa lain yang diabadikan Djoko Pekik yaitu pada saat Sri Sultan Hamengku Buwono IX meninggal dunia, dirinya mengabadikan dalam bentuk karya yang diberinya judul Kawulo Gonjang-ganjing. "Lukisan ini diungkap sebagai perbandingan tentang perbedaan yang mencolok dari kedua peristiwa. Perbedaannya adalah pada Kawulo Gonjang-ganjing rakyat kehilangan panutannya sehingga memunculkan duka dan haru yang mendalam. Namun dalam karya Indonesia 1998 Berburu Celeng, kawulo itu ingin memburu, bahkan ingin menangkap dan menumpas celeng. Kawulo yang dimaksud dalam lukisan tersebut termasuk di dalamnya adalah Golkar yang selama ini selalu manut dan setia pada Soeharto"(Djoko Pekik: 2013).

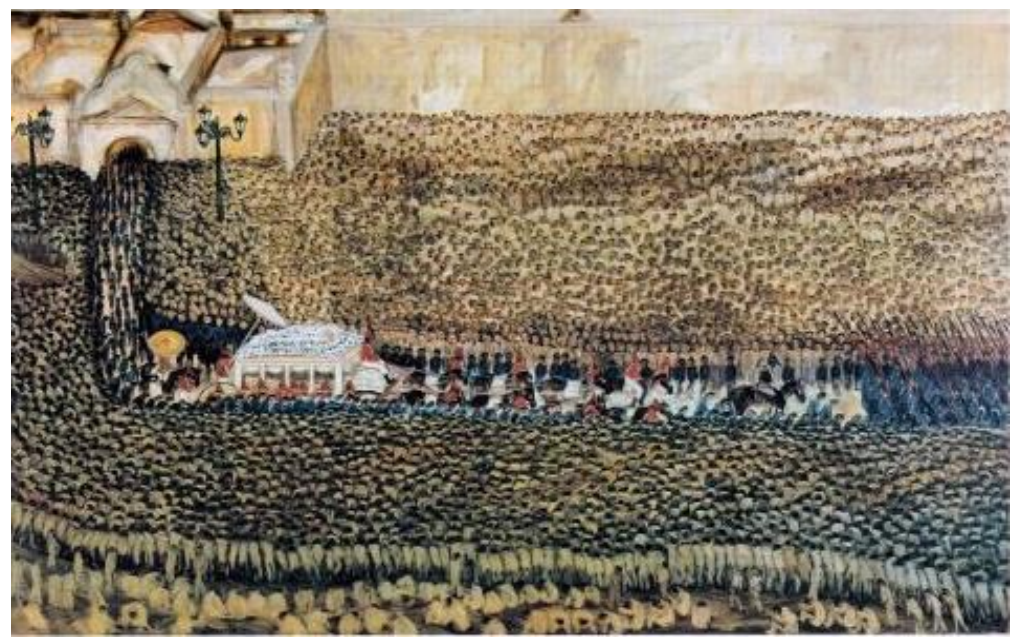

Gambar 6.

Lukisan bertajuk Kawulo Gonjang-ganjing, 1998. (Reproduksi dari katalog pameran tunggal lukisan Djoko Pekik di Galeri Taman Budaya Surakarta)

Bagian lain lukisan Indonesia 1998 Berburu Celeng nampak rakyat sedang berpesta kegirangan di tengah hutan yang ditumbuhi gedung-gedung bertingkat dan jalan layang yang melintang. Pada 
bagian kiri nampak citra dua figur manusia bertelanjang dada dan bercelana pendek hitam sedang menggotong celeng yang diikat keempat kakinya dengan posisi terbalik. Mereka memikulnya dengan sebilah bambu menuju ke kerumunan tengah massa dengan maksud mempermalukannya. Sementara kedua figur manusia telanjang menggotong babi yang terkulai terlihat disebelahnya rombongan penari ledek Ponorogo mengenakan kaus bergaris dengan warna hitam, merah, dan putih merah dengan lengan panjang serta bertopeng putih. Bersama rombongan nampak penari, tangan-tangan terkepal, dan wajah-wajah penuh amarah.

Tertangkapnya babi hutan dalam lukisan ini, tampaknya memiliki pengertian runtuhnya kekuasaan yang telah menyergap Indonesia selama puluhan tahun dan dianggap telah menggerogoti serta menindas hak rakyat. Akibat dari kesewenangan dan keserakahan penguasa maka rakyat menjadi miskin karena adanya kolusi, korupsi, dan nepotisme yang dihalalkan. Hal tersebut berimplikasi pada negeri yang mengalami krisis moneter berkepanjangan dan sulit ditanggulangi dalam waktu cepat. Kemarahan rakyat tidak terbendung lagi dan rakyat bersatu meburu, menangkap, dan mengikat celeng. Penguasa orde baru menggunakan kebijakan-kebijakan yang menurut pelukis membuat banyak hal yang tidak baik. Kini pembuat kebijakan tersebut tidak berkutik di tangan rakyat padahal telah berkuasa selama kurang lebih 32 tahun. Peristiwa tersebut kemudian melatar belakangi Djoko Pekik dalam berkarya. Menurut Djoko Pekik seorang pelukis harus mampu melihat ke depan tanpa harus meninggalkan masa lalu dan sekarang.

\section{c. Latar Belakang Lukisan Trilogi Celeng III (Tanpa Bunga dan Telegram Duka)}

Lukisan berjudul Tanpa Bunga dan Telegram Duka merupakan kelanjutan peristiwa dengan citraan mengubur celeng. Sebelum peristiwanya terjadi sebenarnya gagasan telah lama muncul. Seperti halnya dalam cerita novel, sinetron, atau film yang selalu mengakhiri kisah cerita bisa bahagia atau juga duka. Pada kisah celeng pun lukisannya harus diakhiri tentunya dengan sangat memalukan. Ada 
berbagai gagasan muncul dibenak Djoko Pekik bagaimana akan digambarkan celeng yang berakhir itu. Apapun gagasan yang muncul, selalu terkait dengan rasa dendam yang selalu disimpannya sejak dulu. Kebencian yang tidak kunjung reda dan sangat mendalam sehingga memunculkan gagasan celeng yang mati penuh dengan kehinaan.

Konteks karya lukis, Djoko Pekik mencoba menafsirkan peristiwa melalui cara membaca perkembangan situasi-situasi Indonesia dari berbagai media kemudian melakukan dialog tentang situasi negeri yang carut marut dengan rekan seniman atau temanteman yang berkunjung ke tempatnya. Semua yang dibacaa, fenomena yang terjadi, dan dialognya dengan para seniman menjadi perenungan terutama ketika dalam kesendirian. Hasil perenungan tersebut kemudian diwujudkan dalam bentuk karya lukis.

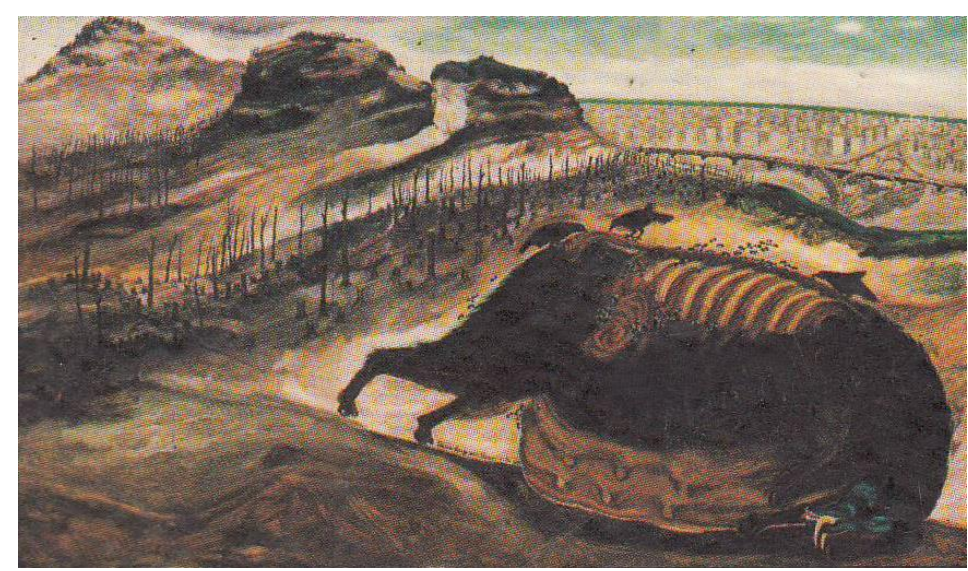

Gambar 7.

Djoko Pekik. Tanpa Bunga dan Telegram Duka. Tahun 2000,1999 (Foto: Dilla Eka Lusiana)

Lukisan itu menggambarkan bangkai celeng yang membusuk tergeletak di pegunungan tandus. Seluruh pohon-pohon meranggas, bukit-bukit gundul, lalat-lalat hijau berkerumun di tubuh celeng yang kulitnya mulai mengelupas. Dua gagak hitam memasuki dagingnya sehingga tulang iganya menyeruak dan terlihat karena dagingnya mulai habis dimakan. Samar-samar dibalik bukit terlihat panorama kota dengan jalan layangnya. Kematian celeng sangatlah terasa memilukan yang digambarkan penuh dengan kesepian, dalam kesendirian, dan tidak terurus. 
Hal yang melatar belakangi tema utama pada lukisan bertajuk Tanpa Bunga dan Telegram Duka adalah lambang matinya angkara murka dan harapan akan datangnya ratu adil. Matinya angkara murka di tahun 2000 merupakan sebuah ide dasar Djoko Pekik, tentang situasi dan kondisi di Indonesia pada tahun tersebut serta harapan baru memasuki abad milennium terhadap pemimpin negeri ini yang dapat mengayomi rakyat. Djoko Pekik mungkin juga terinspirasi dari sejarah tentang sosok mantan penguasa seperti dialami oleh Soekarno yang diisolasi di Wisma Yaso. Soekarno dikurung tidak boleh bertemu siapapun tanpa ijin dan keluar dari pintu rumah bahkan jalan-jalan dihalaman rumah pun dilarang. Suatu kondisi yang mampu membuat jiwa seseorang tertekan dan depresi.

Sejarah sukses di Jawa, rakyat biasanya akan memaafkan penguasa yang sudah tidak bertahta lagi. Bagi raja kemungkinan pilihannya hanya dua dibunuh atau dibuang tergantung pada kebijakan penguasa baru. Dalam penguasa Mataram sanak famili penguasa zalim oleh rakyat pasti akan dikucilkan. Kematian Raja Celeng menurut versi Djoko Pekik bahwa celeng ini mati secara alami dan dibiarkan begitu saja, tidak ada yang memberi karangan bunga, tidak ada yang mengurusi pemakamannya. Kematian Raja Celeng tersebut menyisakan berbagai permasalahan yang diwariskan secara langsung bagi generasi berikutnya.

\section{Makna Visual Trilogi Celeng Karya Seni Lukis Djoko Pekik}

Terdapat tiga jenis tanda Pierce yang pada umumnya digunakan dalam mengurai karya-karya yang memiliki semiotika. Ketiga jenis tanda tersebut adalah simbol, ikon, dan indeks. Simbol adalah tanda yang mewakili objeknya melalui kesepakatan atau persetujuan dalam konteks spesifik (Danesi, 2012: 32). Dengan kata lain, simbol bukan merupakan fakta-fakta yang sudah jadi, simbol berada dalam proses yang kontinyu. Adanya simbol-simbol tersebut, lahirlah tema-tema yang mempunyai makna dan dapat berinteraksi dengan para penontonnya.

Ikon adalah tanda yang mewakili sumber acuan melalui sebuah bentuk replikasi, simulasi, imitasi atau persamaan (Ibid, 2012:32), sedangkan 
indeks adalah tanda yang mewakili sumber acuan dengan cara menunjuk padanya atau mengaitkannya (secara eksplisit atau implisit) dengan sumber acuan lain (Ibid, 2012: 32)

\section{Kajian Makna Lukisan Susu Raja Celeng}

\section{Analisis Ikonik Lukisan Susu Raja Celeng}

Citra celeng dalam lukisan Susu Raja Celeng ini merupakan sejenis hewan mamalia babi hutan yang hidup liar, buas, dan rakus. Citra celeng kehadirannya sangat menonjol jika dibandingkan dengan objek lainnya. Tubuh yang begitu besar penggambarannya seperti celeng raksasa. Celeng yang sedang berkeliaran di lapangan di tengah kota besar nampak begitu kuat dan perkasa. Keperkasaannya terlihat dari bentuk tubuh tegap dan ketajaman taring-taringnya yang salah satu fungsinya dapat digunakan sebagai senjata. Di bawah tubuhnya yang begitu besar nampak perut yang tambun dengan keenam puting susunya. Pada belahan bidang gambar tepatnya dibawah taring celeng nampak warna merah menggenangi tanah yang dipijak celeng.

Pada latar bagian belakang citra tubuh celeng berwarna hitam dan tambun nampak di kejauhan garis yang membentang secara diagonal membentuk jembatan layang lengkap dengan lalu lalang kendaraan yang melintasinya. Pada jembatan layang sudut penggambaran ditampakkan dari atas sehingga keramaian lalu lalang kendaraan yang melintasinya dapat diperlihatkan dengan jelas bagitupun kerumunan massa yang berada di bawahnya.

Sudut penggambaran pada celeng dan gedung-gedung digambarkan dari arah wajar sehingga bentuk tubuh celeng dapat dikenali dengan jelas begitupun dengan bangunan-bangunan pencakar langit dapat terlihat jelas dan menjadi latar bagian belakangnya. Dibawah gedung-gedung bertingkat yang berdiri angkuh nampak citra rumah-rumah sederhana. Dalam lukisan ini nampak awan biru bercampur awan hitam.

\section{Analisis indexial Lukisan Susu Raja Celeng}

Lukisan Susu Raja Celeng terlihat seekor celeng sedang dikepung oleh masa di lapangan yang tempatnya berada di tengah kota. Celeng tersebut nampak 
sangat besar, kuat dan perkasa. Melihat dari bentuk perut tempat bersarangnya enam susu tersebut dapat ditafsirkan bahwa begitu banyak air susu yang dimilikinya.

Celeng dengan bentuk tubuhnya yang besar, kekar dan tambun celeng terlihat jahat. Kerumunan masa yang ada pada lukisan Susu Raja Celeng dapat diinterpretasikan sedang melakukan perburuan binatang celeng karena lepas dari habitatnya yaitu hutan. Celeng tersebut telah berpindah ke tengah kota dan mengkonsumsi wilayah kota. Dengan demikian ia berhadapan dengan amuk massa yang merasa tercuri atau terhisap harta bendanya. Celeng tersebut tampak gemuk dan tambun karena memakan harta masyarakat.

\section{Analisis Simbolik Lukisan Susu Raja Celeng}

Ibarat manusia-manusia seperti celeng yang serakah banyak ditemukan bukan hanya pada rakyat kecil namun sering dijumpai dari kalangan penguasa daerah dan Negeri ini, wakil rakyat, atau pengusaha. "Di antara kedua objek yang diacu oleh tanda celeng dan penguasa terutama dalam sifat yang dimiliki yaitu buas dan rakus. Dengan kata lain citra celeng yang dihadirkan dalam lukisan yang bertajuk Susu Raja Celeng ini adalah metafora bagi seorang penguasa"(Djoko Pekik: 2013).

Pencitraan tubuh tambun dan besar pada celeng dalam lukisan ini dapat menjadi sebuah tanda yang mengarah pada suatu kebiasaan pada pola makan yang berlebihan sehingga menyebabkan bentuk tubuhnya menjadi gemuk atau tambun. Enam susu besar dalam lukisan Susu Raja Celeng dapat diinterpretasikan sebagai suatu sumber kehidupan bagi keturunannya atau anak-anak dari Raja Celeng. Sumber hidup bagi keturunan dalam dunia nyata merupakan sinonim sebagai harta yang akan diwariskan kepada keturunannya. Fungsinya baik susu dan harta sebagai sumber kehidupan bagi generasi selanjutnya atau anak-anaknya.

Tatapan mata celeng agak terlihat sayu sebagai penanda umur yang tua. Kekuatan yang dimiliki tersebut ditempatkan dalam lukisan yang diperlihatkan dari keberingasan tatapan mata yang tajam. Pencitraan raja celeng dengan tubuh hitam dapat dibaca sebagai suatu simbol dari bentuk kekuatan dan keperkasaan. Penggambaran tubuh berwarna hitam pada celeng merupakan simbol dari sifat negatif yang ada pada diri celeng. 
Kekuatan atau kekuasaan yang dimiliki celeng dapat dilihat dari empat taring yang sangat tajam bertengger di kepalanya. Taring pada celeng berfungsi ganda selain untuk alat menggaruk tanah dalam mencari makanan juga dapat digunakan sebagai senjata untuk mempertahankan diri. Dapatdiartikan celeng yang dengan kesewenangannya merampas harta milik rakyat melalui sifatnya yang buas dan rakus pada akhirnya diruntuhkan oleh masa.

\section{E. Kajian Makna Lukisan Indonesia 1998 Berburu Celeng}

\section{Analisis Ikonik Lukisan Indonesia 1998 Berburu Celeng}

Konfigurasi tanda-tanda di dalam lukisan Indonesia 1998 Berburu Celeng "terlihat lebih kompleks dari sebelumnya. Citraannya memperlihatkan jembatan layang dengan latar di bagian belakang gedung-gedung bertingkat. Pusat perhatian dalam lukisan pada karya ini adalah celeng tambun dengan mata sayu dibagian kepala yang tertutup bulu tebal yang digotong oleh dua figur manusia bertelanjang dada dan paling menonjol dibanding dengan objek-objek lain.

Belahan kanan lukisan nampak kerumunan orang menggunakan pakaian adat khususnya para perempuan sertsa wajahnya menggunakan make-up putih seperti topeng. Tempak kelompok kesenian reog sedang menari dengan raut wajah tampak suka cita. Kelompok kesenian reog tersebut seolah mengiringi atau menyambut dua figur manusia yang sedang menggotong binatang buruannya. Para penari reog digambarkan layaknya dalam suasana karnaval yang penuh dengan keriangan dan terlihat kocak seperti umumnya terjadi pada pesta yang diselenggarakan oleh rakyat. Suasana yang riuh dan penuh kocak menjadikan citraannya seperti sebuah pawai kemenangan yang heroik karena binatang yang selama ini diburu telah tertangkap. Ditengah kerumunan para penari atau orang-orang yang sedang bersuka cita merayakan kemenangan nampak sosok manusia sedang melakukan pantomim Dalam suasana penuh suka cita yang digambarkan seperti karnaval yang riang dan penuh kocak terselip sosok laki-laki berbadan kekar mengenakan baju berwarna kuning dan bersepatu laras tinggi seperti yang selalu dipakai oleh tentara. 
Kerumunan massa dibawah jembatan yang terlihat sepi dengan latar belakang gedung-gedung bertingkat bukanlah sedang melakukan perayaan namun sedang melakukan perburuan. Di belakang para penari dan ketidakberdayaan celeng dalam kondisi terikat pada sebilah bambu nampak lautan manusia tumpah ruah. Di tengah lautan manusia tampak sekelompok orang membawa dan membentangkan spanduk. Tulisan-tulisan tersebut tidak akan terlihat jelas karena demonstran yang membawa spanduk di tempatkan jauh dan yang nampak hanya bentangan saja.

Kerumunan massa nampak sosok-sosok manusia memakai kacamata. Sosok Manusia berkacamata digambarkan dengan kepala botak di bagian kepala, mengenakan pakaian safari lengkap dengan tanda kepangkatan di pundak, dan sosok lainnya berada tepat di belakang celeng mengenakan pakaian putih dan rapi.

Citraan pada lukisan bertajuk Indonesia 1998 Berburu Celeng sepertiga bidang bagian atas didominasi warna gelap atau hitam. Pada bidang bagian atas nampak citra langit cerah berpadu dengan awan-awan yang menggumpal berwarna hitam. Walaupun awan hitam nampak di beberapa bagian namun kecerahan langit masih nampak mendominasi. Tarikan garis begitu kuat yang terpadu dengan sapuan warna hitam membentuk citra jembatan layang dan sekaligus menjadi pembatas antara langit dengan objek gambar yang berada di bawah. Di antara lorong-lorong yang dibentuk oleh tiang-tiang beton penyangga jalan layang nampak di kejauhan kemegahan gedung-gedung bertingkat berdiri dengan angkuh.

\section{Analisis Indexial Lukisan Indonesia 1998 Berburu Celeng}

Celeng dalam lukisan bertajuk Indoneisa 1998 Berburu Celeng merupakan celeng tambun yang buas dan rakus manakala sedang berkuasa, justru terlihat dalam posisi tidak berdaya. Celeng yang diikat pada sebilah bambu memperlihatkan peristiwa tertangkapnya celeng di tengah kota tentu terkait dengan peristiwa sebelumnya karena ulah kejahatan yang dilakukan celeng. Pada lukisan Berburu Celeng justru kekuasaannya menjadi hilang walau celeng tersebut masih mempunyai taring yang indah dan perkasa. Dalam konteks lukisan ini merupakan pesta atas tertangkapnya celeng yang dianggap sebagai binatang yang meresahkan masyarakat. 
Terikatnya celeng pada sebilah bambu yang ditandu oleh figur manusia kurus kering memperkuat citra ketidakberdayaan dan menjadi penanda hilangnya kekuasaan yang selama ini dimiliki. Betapa besar dan perkasanya celeng tersebut terlihat tampak tidak berdaya, badannya dijungkir, dan kakinya diikat pada bambu. Jika dilihat dengan teliti maka pada celeng nampak mata sayu dibagian kepala yang tertutup bulu tebal. Penggambaran mata yang tentunya tidak diperlihatkan dengan jelas atau nampak kecil karena cara penggambaran sesuai dengan objek sebenarnya. Tatapan mata tersebut merupakan kesedihaan mendalam yang dirasakan atau diungkapkannya di tengah-tengah ketidakberdayaan.

Kelompok barisan nampak para penari ledek dan terselip juga para pemain pantomim. Penempatan kelompok orang di bagian depan bersebelahan dengan celeng yang digotong tentunya menjadi pusat perhatian. Dapat dikatakan bahwa rakyat sangat bersuka cita karena tertangkapnya celeng.

\section{Analisis Simbolik Lukisan Indonesia 1998 Berburu Celeng}

Lukisan Indonesia Berburu Celeng 1998, raja celeng yang memiliki similaritas dengan penguasa yang buas dan rakus diperlihatkan tergantung dan terikat pada sebilah bambu dalam kondisi tidak berdaya yang digotong kedua figur manusia-manusia kurus . Ketidakberdayaan raja celeng diakibatkan karena ulah perbuatannya sendiri yang memakan hak rakyat. Ukuran badan dua figur manusia kurus tersebut bertolak belakang dengan celeng gemuk sebagai metafora sang penguasa negeri.

Konteks lukisan berjudul Indonesia 1998 Berburu Celeng citraannya merupakan potret peristiwa yang terjadi. Penguasa digambarkan secara samar dalam bentuk celeng. "Peristiwa yang terjadi pada 1998 merupakan catatan dalam sejarah Indonesia namun pada saat ang sama merupakan kemenangan bagi rakat Indonesia ketika penguasa negeri dapat ditumbangkan"(Djoko Pekik: 2013).

Sosok kedua figur manusia digambarkan telanjang dada dengan kulit hitam legam, bertubuh kurus seperti busung lapar yang menjadi penanda kondisi rakyat jelata. Tubuh-tubuh kurus merupakan representasi keadaan rakyat kecil yang serba kekurangan dan dapat dikatakan sebagai simbol dari beban hidup yang ditanggungnya. Segala penderitaan dalam kehidupan 
dijalani dengan penuh kesabaranserta daya hidup untuk pemicu atau semangat walau selalu manjadi korban atau tumbal dalam derap pembangunan. Semangat yang begitu tinggi pada rakyat dipresentasikan dalam lukisan ketika mampu menggotong celeng dan mengarak walaupun tubuh celeng begitu besar dan membebani pundaknya. Dengan demikian dapat disebutkan bahwa dua figur manusia penggotong celeng merupakan simbol dari semangat rakyat kecil dalam menjalani hidup walaupun bebannya terlalu berat. Dengan daya hidup tersebut maka segala beban hidup yang berat dapat dijalani.

\section{F. Kajian Makna Lukisan Bertajuk Tanpa Bunga dan Telegram Duka}

\section{Analisis Ikonik Lukisan Bertajuk Tanpa Bunga dan Telegram Duka}

Konfigurasi tanda-tanda di dalam lukisan Tanpa Bunga dan Telegram Duka terlihat lebih kompleks. Citraannya memperlihatkan seekor celeng, tubuhnya tersungkur di tanah dalam kondisi sudah mati. Celeng yang besar tersebut berada pada lereng pegunungan yang gundul dan gersang dengan batang-batang pohon yang nampak menghitam akibat kebakaran yang terjadi. Tanda lain yang dilihat dari akibat terbakarnya hutan nampak pada tanah berwarna hitam bekas dari ilalang yang hangus ikut terbakar.

Terlihat di belakang celeng yang tergeletak area perbukitan dan dibelakanya nampak di kejauhan jembatan layang serta gedung-gedung bertingkat tetap berdiri seolah menjadi saksi bisu setiap peristiwa yang terjadi. Diantara deretan gedung-gedung yang berderet rapi jika diamati terlihat Tugu Monas dan istana negara. Dari ketinggian tempat tubuh celeng dibuang dapat dilihat juga barisan tentara. Lautan massa yang berjubel sebagai demonstran masih berdatangan seolah seperti banyu gembrojok (air membanjir) walau celeng yang diburu sudah mati.

Terlihat bukit kering dan tandus tempat terbuangnya bangkai tubuh raja celeng nampak pemandangan indah. Dikejauhan terlihat bentangan laut luas dan tenang setidaknya panorama alam yang indah nampak dikejauhan kontrasdengan pemandangan bukit yang gundul dan kering. Dari atas bukit itu pula dapat terlihat pemandangan ibu kota lengkap dengan segala 
keriuhan di dalamnya seolah jarak antara ibu kota dengan bukit gundul tidak terlalu jauh.

\section{Analisis Indexial Lukisan Bertajuk Tanpa Bunga dan Telegram Duka}

Raja celeng yang besar dan perkasa pada akhirnya menemui ajal secara mengenaskan. Lukisan berjudul Tanpa Bunga dan Telegram Duka menjadi akhir dari kehidupan celeng. Keangkuhan, keangkaramurkaan dan segala bentuk kekuasaan pada akhirnya menjadi pupus atau hilang begitu saja. Terlihat Raja celeng yang mati tubuhnya dibiarkan begitu saja sampai membusuk. Perutnya jebol memamerkan usus dan rusuknya yang menonjol di atas bukit gersang.

Tubuh raja celeng yang dibiarkan tergeletak di atas bukit gersang dengan kondisi megenaskan seolah mati secara alamiah. Dari tubuhnya yang membusuk tidak terlihat lagi tanda kemegahan, kekuasaannya, atau kebesarannya seakan tertutupi oleh kebusukannya yang tercium kemana mana. Kematiannya justru dirayakan dengan penuh suka cita oleh para pemburunya dan dianggap suatu kemenangan rakyat atas jerih payah dalam melakukan perburuan.

Tubuh celang dengan usus yang berurai keluar merupakan indeks dari suatu peristiwa tertentu seperti terjadinya pertarungan antara celeng dengan binatang lain yang menyebabkan celeng kalah dan mati. Penyebab lain matinya celeng akibat diburu oleh manusia karena menjadi hama yang merusak tanaman diladang dan sawah para petani. Dalam indeks yang berelasi dengan kejadian sebelum kematian celeng yang paling tepat adalah indeks yang kedua mengingat indeks pertama yang kematiannya diakibatkan karena pertarungan dengan binatang buas katakanlah singa atau harimau tentu tubuh celeng ini habis dimakan kedua binatang tersebut sehingga efeknya mungkin tubuh celeng tidak seutuh seperti dalam lukisan.

Pembusukan yang terjadi secara alami pada tubuh raja celeng ditampakkan pada wajahnya. Wajah raja celeng yang dulunya memperlihatkan keberingasan dengan senjata berupa taringnya yang tajam kini menjadi sirna yang digambarkan dengan wajah hijau kebiruan. Pembusukan yang terjadi pada tubuh celeng berakibat pada tidak 
berfungsinya organ tubuh lain. Akibat pembusukan tersebut maka secara otomatis keenam susunya sebagai sumber kehidupan menjadi tidak berfungsi.

\section{Analisis Simbolik Lukisan Bertajuk Tanpa Bunga dan Telegram Duka}

Celeng yang dihadirkan dalam lukisan sebagai metafora dari penguasa dianggap pembawa bencana bagi Negaranya ternyata tidak berkutik mana kala rakyat yang tumpah ruah seperti banyu gembrojok memburunya. Raja celeng yang besar dan perkasa pada akhirnya menemui ajal secara mengenaskan dalam kesendirian dan kesunyian yang mencekam.

Kematian raja celeng merupakan representasi dari akhir bagi penguasa yang selama hidupnya penuh dengan kesombongan, ketamakan, dan mementingkan dirinya sendiri. Kematian celeng merupakan idiom matinya seorang penguasa akibat dari penyalahgunaan kekuasaan.

Air Susu yang diinterpretasikan sebagai suatu sumber kehidupan bagi keturunannya atau anak-anak dari raja celeng kini sudah tidak dapat disedot lagi. Dengan kata lain air susu yang kering merupakan simbol makanan yg mudah didapat selalu disediakan sudah tidak ada lagi. Bersamaan dengan runtuhnya kekuasaan yang dimiliki raja celeng berdampak pada kehidupan anak-anaknya.

\section{KESIMPULAN}

Dari tahapan penelitian serta analisis dapat ditarik kesimpulan tentang aspekaspek penting yang berkaitan dengan munculnya lukisan-lukisan Trilogi Celeng. Aspek tersebut adalah pengalaman-pengalaman pahit masa lalu yang pernah dialami oleh Djoko Pekik. Wujud penggambaran lukisan Djoko Pekik Trilogi Celeng yang begitu apik bukanlah hanya sekedar peristiwa seperti yang terlihat atau terpersepsi, namun jauh di balik itu terdapat banyak makna atau pesan yang ingin disampaikan. Celeng yang digambarkan Djoko Pekik merupakan idiom atau simbol dari tingkah laku manusia yang mempunyai kesamaan sifat dengan manusia yang serakah, buas, dan rakus seperti halnya penguasa orde baru. Trilogi Djoko Pekik terdapat aspek penting yaitu pengalaman masa lalu yang pahit dan trilogi celeng ini menunjukan fase jatuhnya orde baru. 
Melalui pembahasan dengan teori semiotika Pierce terdapat tiga tanda didalamnya yaitu dalam fase Ikon. Ikon adalah tanda yang mewakili sumber acuan melalui sebuah bentuk replikasi, simulasi, imitasi atau persamaan. Face Indeks adalah tanda yang mewakili sumber acuan dengan cara menunjuk padanya atau mengaitkannya (secara eksplisit atau implisit) dengan sumber acuan lain. Fase Simbol adalah tanda yang mewakili objeknya melalui kesepakatan atau persetujuan dalam konteks spesifik.

Realisme pada lukisan Trilogi Celeng merupakan suatu lukisan yang mudah secara teknis, dimengerti rakyat, dan secara idiologis mengabdi rakyat. Situasi dan kondisi yang berkembang di tanah air, menjadi salah satu ide dasar yang melatar belakangi munculnya lukisan Trilogi Celeng Djoko Pekik ini. Peristiwa lengsernya Presiden Soeharto dari tahta kepresidenan menjadi hal yang menarik untuk diangkat menjadi sebuah lukisan.

\section{DAFTAR PUSTAKA}

\section{Buku:}

Antariksa. 2005. Tuan Tanah Kawin Muda: Hubungan Seni Rupa LEKRA 19501965. Yogyakarta: Cemeti

Danesi, Marcel. 2012. Pesan, Tanda, dan Makna: Buku Teks Dasar Mengenai Semiotika dan Teori Komunikasi, Yogyakarta : Jalasutra.

Siregar, TH Aminudin. 2004. Lukisan Baru setelah Lukisan Non-Repesentasional di Bandung. Bandung Galeri Kita.

\section{Wawancara:}

Djoko Pekik di kediamannya di Jl. RE. Martadinata No. 38 Yogyakarta, pada tanggal 16 Mei 2013.

\section{Katalog:}

Yuliman, Sanento. "Seni Djoko Pekik", katalog pameran tunggal lukisan Djoko Pekik di Galeri Taman Budaya Surakarta, Yogyakarta: Bentang Graphic Design. 1993 